\title{
The Lure of Autocratic Education in a Somewhat Democratic Society
}

\author{
By Xenia Coulter ${ }^{*} \&$ Lee Herman ${ }^{\dagger}$
}

The United States (US) has since its inception considered the education of its citizens as critical for preserving democracy. The recent attractiveness of autocratic leaders, not only in the US but across the world, raises questions about the dominant educational model now in place. We argue that the authoritarian and business-oriented structure and the information delivery model of learning today produce students who learn to rely on readymade answers from those in authority. We describe, in contrast, the educational practices and philosophies of John Dewey and Socrates that expect students to find and evaluate their own answers. We also describe our experiences as professors in an American public university that for some time promoted through its policies and procedures equality between teacher and student and diversity among students through individualized learning activities. The result, we argue, were students comfortable with dialogic learning, collaborative inquiry, and independent thinking. We also describe how, despite its initial promise, our college, along other such schools, could not be sustained. We suggest that while the fragility of democratic education may be due to external factors over which we have no control, it is also due to certain human traits: a predisposition for efficiency and immediate decision-making, which makes it difficult to acknowledge ignorance or engage in self-examination; and the need for control, the lure of power and its corollary, the will to submit. If teachers would critically examine their reliance upon lectures, textbooks, and exams and consider other models of teaching, we believe they could, within their own classrooms, create communities of dialogue, collaboration, and free thought. We call upon both teachers and students to explore ways of learning that are inherently democratic and will help democracy, not autocracy, flourish in society and all its institutions.

Keywords: democracy, Dewey, dialogue, progressive education, Socrates.

\section{Introduction}

Every government degenerates when trusted to the rulers of the people alone. The people themselves, therefore, are its only safe depositories. And to render even them safe, their minds must be improved to a certain degree. This indeed is not all that is necessary, though it be essentially necessary. An amendment of our constitution must here come in aid of the public education. Thomas Jefferson (2011, p. 254)

The recent emergence of populist autocratic leaders in nations across the world, including the United States, raises questions about the role of education in encouraging this alarming development. The United States has since its inception regarded education as critical to forming and sustaining democracy. Even as the US Constitution was approved, Thomas Jefferson called for citizen education as key to the success of this new experiment in government. Leaders in any situation,

*Professor Emerita, SUNY Empire State College, USA.

†Professor Emeritus, SUNY Empire State College, USA. 
he argued, will inevitably succumb to tyranny; and in a democracy, only the people have the power to prevent this from happening. To be aware of this danger and to know how to respond, people must be educated. It is from this tradition that we as American educators, ask now whether educational institutions and practices might be changed so as to prevent or at least temper the current lure of autocracy.

In this article we will argue that in our colleges and universities today, it is not surprising that our graduates seem disturbingly comfortable in autocratic social, political and economic environs. We will then describe the educational practices and philosophy of John Dewey on the one hand and Socrates on the other that were exquisitely in tune with the structure and goals of a democratic society. We will also describe our own experiences as professors in an American public university which in its policies and procedures, for a short period in its history, promoted equality between teacher and student, and the kind of free but responsible thinking and openness to diversity that a democracy demands. Most importantly, we will describe how, despite its promising beginning, our college increasingly obstructed its democratic mission as it inexorably moved back to a traditionally hierarchical and autocratic culture. This development has prompted us to wonder about the ways in which teachers might be better prepared to defy the pressures that constrain their efforts to prepare students for democratic living - if indeed they can be persuaded to make such efforts.

\section{Education Today}

Perhaps it is not that remarkable that the predominant customs and methods of teaching in our somewhat democratic societies are strictly hegemonic. Classroom teachers have absolute or nearly absolute authority over what is to be learned, how it is to be acquired, and how it is to be assessed. Students, if they hope to graduate, are expected to submit to this authority. Teachers themselves, especially in colleges and universities, operate in an august hierarchy of the tenured and untenured, the full professors and the lesser ones. It seems unlikely that persons steeped in modern day academic culture - both students and teachers - could ever learn to recognize the dangers of tyranny much less the importance in a democratic society of resisting it. Indeed, it is also unlikely that most American teachers are even aware of the role originally assigned to them by the founders of American democracy - that is, to prepare their students to be citizens who will protect and nurture the freedoms democracy affords and shoulder the responsibilities it requires.

It is not only that teachers have succumbed to the lure of autocracy, but so too has the entire educational enterprise. Educational institutions fit well with the largely non-democratic cultures of businesses and of social and civil service bureaucracies. These are the non-academic institutions in which many higher education graduates will likely find employment. One could credibly argue that college and university administrators across the world actively seek equal status with existing political and economic power brokers. Indeed, college presidencies are often semi-autocratic positions (for example, Articles IX and X in State 
University of New York, 2014). In the institutions they control, a standardized curriculum is delivered through mandatory textbooks and the learning assessed by lengthy exams, both being produced by huge publishing and testing companies. Within such an autocratic-seeming world there is very little room for students to experience, appreciate, and respect freedom of thought and action. They learn to favor unequivocal answers to intellectual and practical questions, while also learning to complete their academic work with the least time and effort. Thus, they seek certainty, simplicity, homogeneity and efficiency - the virtues of power. How can we be surprised then when our graduates, rather than stimulated and enriched, feel threatened and uncomfortable with uncertainty, diversity, and complexity in the real world? It should also not be a surprise that even the most educated look for the "right answers" from those in power and that they feel frustrated, humiliated, and angry when confronted by situations that are not simply and easily resolved. Over the many years our citizens now spend in school, when do they ever have a chance to practice hearing the unrecognized, listening to the less powerful, making decisions for themselves, and learning how to evaluate and modify their positions with new information? Instead, graduates of our schools would seem well prepared to thrive not in democratic but autocratic societies. Because democracies do fail (see e.g., Adorno, Frenkel-Brunswik, Levinson \& Sanford, 1950; Levitsky $\&$ Ziblatt, 2018), this phenomenon is of great concern.

\section{Dewey's Philosophy}

One hundred years ago, John Dewey, arguably the most notable and perhaps the most "American" of philosophers from the United States, exposed this alarming disconnect between the education as it was actually practiced and the democratic life that Americans professed (Dewey, 1916). He asserted that education should mirror the society in which it takes place. Thus, students in democratic schools should be able to experience the same freedoms promised by the democratic society in which they live. Education is not preparation for life, Dewey argues (p. 54-56), but a microcosm of life itself. In a classroom that models a democratic society, teachers treat students as though they are their own agents in learning. Gert Biesta (2017), a modern-day philosopher of education from the United Kingdom, describes the teacher/student relationship similarly: Students, instead of being treated as taught objects, are regarded as autonomous subjects, capable and intelligent enough to learn on their own when helpfully invited to do so.

For both Dewey and Biesta, such an approach to education mirrors what should take place in a society where people are free to follow their own desires, but disciplined enough to hone their own wants and acknowledge those of others (Biesta, 2017, calls this combination of discipline and freedom "grown-up"). This is what psychologists mean by being "assertive," that is, inhabiting a kind of middle ground between being "aggressive" at one end and "passive" at the other (see, e.g., Murphy, 2011). Whereas Dewey and Biesta mostly focused on the education of children, Lindeman (1927), a strong supporter of Dewey's, showed 
that these ideas were equally relevant to the education of adults. Indeed, in our own experience, such methods of teaching are applicable to not just traditionalaged college students, but to any adult seeking a university education.

Dewey's major book, Democracy and Education (1916), plus many shorter articles about his experiences as the director of an elementary school he created as a laboratory, delved deeply into the ways in which an education appropriate to a democracy might be carried out. For him, the chief enemy of education in a democracy was standardization. In order to maximize diversity, Dewey envisioned a school where each student's unique configuration of interests, talents, and goals, could be recognized and developed. In that way, schools were expected to nurture a highly diverse population with a variety of strengths that, in adulthood, could be applied to the as yet unknown but inevitable challenges of the future. Such individuality was promoted by offering students hands-on experiences or provocative problems that gave learners space in which to take charge of their own learning as they contemplated in their own ways the knowledge these experiences were designed to evoke. Additionally, students worked together as they shared back and forth their varied insights and ideas, and in so doing they came to appreciate the value of multiple thoughts in revising their own initial reactions and in discovering the best possible solutions. A podcast by Finkel (2015) provides excellent examples of this process in teaching mathematics. The viewer can easily see the learning advantage that accrues when a teacher refuses to give a class of students the right answers but instead provides them with enough time and space to not only come up with their own answers but to figure out for themselves how to validate them.

As exemplified by Finkel, many people advocate for progressive education (the term often applied to Dewey's form of education) for reasons other than its relationship to democracy. For one thing, it is clearly humane: Students consider progressive classes fun (e.g., Mayhew and Edwards, 1936/1967; see also Finkel's insistence, 2015, that learning should be a form of play). Secondly, in terms of learning, which is Finkel's main interest (see also Paley, 1992), the process seems to yield more sustained interest and better-quality comprehension. Moreover, nowhere in Dewey's writings does he propose a curriculum or specific courses related to the concepts or structure of a democratic government. Instead, his focus, and similar to that of Biesta (2017), is on the way students learn together in freedom as equals. Dewey relies on the natural sociability of human beings to help them figure out how to accommodate each other's differences. He also expects that if the learning experiences truly engage them, students will naturally restrain their behavior to accommodate to the situation, just as they readily follow the rules of games such as baseball or soccer (see Dewey, 1938, in particular chapter 4). ${ }^{1}$ Thus, students do not merely learn about democracy; instead, their schooling is itself a democratic practice.

\footnotetext{
${ }^{1}$ It is only when rules are arbitrarily imposed that they become objectionable and elicit resistance
} 


\section{The Socratic Method}

While Dewey emphasized the critical importance of student collaboration, he left largely to the imagination of the reader exactly how learning takes place through discussion and dialogue. In contrast, the Socratic dialogues, as reconstructed by Plato, illustrate in detail the actual activity of communal learning. They are dramas more than texts. That form of presentation is consistent with Socrates being a philosopher who did not write philosophy. As he explains (Plato, ed, 1963, in Phaedrus, 275d), it's not possible to converse with books. You can't ask them questions or explore undeveloped provisional thoughts. For Socrates, learning is always inquiry: He asks a question; the respondent answers by assertion; Socrates asks another question. The process continues as assertions are abandoned when shown to contradict themselves or yield obvious absurdities. Although Socrates is willing to converse with any person interested in engaging with him, whether publicly (see Plato, ed. 1963 in the Apology) or privately (e.g., in the Symposium and the Republic), certain conditions must be met to sustain the conversation as a genuine search for truth, that is, a truly authentic inquiry:

- Any interested person may participate, because anyone can be a learner.

- Each participant is equally responsible for sustaining and furthering the inquiry.

- Each participant must suppose that his or her ideas are not absolutely true and perhaps not true at all.

- Each participant must be willing to acknowledge his or her own ignorance.

- Each participant must suppose that the ideas of other participants might be true.

- Each participant must treat the other with respect and take his or her ideas seriously and as potentially valuable.

- By the same token, each participant must feel free to speak and to say what he or she really means. This freedom to speak one's mind, the Greeks called parrhesia (see Foucault, 2010, for extensive discussions of this concept).

- The participants must treat one another as both teacher and learner.

- The participants must consider the results of their inquiries as provisional (subject to correction and amplification) and yet consider the indefinitely prolonged activity of dialogical inquiry itself as something stably truthful, just, and precious.

With its emphasis on inquiry open to all, and its insistence that truth is the exclusive property of no one, the Socratic dialogue presents itself as a form of discourse ideally suited to a democratic society. It is learning as an egalitarian social contract.

Nonetheless, it must be noted that while ancient Athens considered itself democratic, in many ways, it was not. Women hardly had the same rights as male citizens; and a large portion of the population were slaves. ${ }^{2}$ And just as Dewey's ideas contrasted with the dominant (and still dominant) form of hierarchical education (see, e.g., Dewey, 1938), so did Socratic practice contrast with an influential form of learning popular in Athens. It was offered by the Sophists,

\footnotetext{
${ }^{2}$ For a more detailed account, see Pomeroy, Burstein, Donlon, \& Roberts, 1999, p. 233-244.
} 
itinerant teachers who sought to deliver to their pupils the information and oratorical facility necessary for political and social success. Importantly, Socrates criticized sophistic education because it violated what he deemed to be the two principles essential for a flourishing human life: The unexamined life is not livable for human beings (Plato, ed. 1963, in the Apology 38d); and wisdom is knowing that one does not know (Apology 21d).

In many ways, these two principles are two sides of the same coin. If we do not take time to carefully articulate our conscious understandings or uncover our tacit beliefs, we are by definition ignorant - doubly so when we are not aware of our ignorance. And an ignorant person not only lacks wisdom but more importantly, also lacks any reason to learn more. For Socrates (and other philosophers who followed him), such a static life is essentially empty. Of course, the discovery of one's ignorance can lead to helpless passivity. Meno, for example, complains that he has been paralyzed by Socrates' logically entrapping questioning (Plato, ed. 1963, in Meno, 80a). It can also cause frustration and humiliation, which in turn can stimulate aggression, for example, Thrasymachus in the Republic (Plato, ed. 1963, 336b-e) and Anytus in the Meno (94e-95a). ${ }^{3}$ However, if we can make our way between paralysis and anger to what Biesta calls a "middle ground" (2017, p. 13), the discovery of ignorance can inspire curiosity, energize further inquiry, and generate sustained dialogue.

In countless ways, such a striving for knowledge and truth is both useful and necessary for a thriving democracy. As Habermas astutely observed (1990), the dialogical interaction (which he calls "communicative action") is at the same time ethical and political. To start with, the dialogical relationship promotes and depends on an equality between the participants. All answers as well all questions must be taken seriously. It's the dialogical back and forth that matters as much as whatever provisional conclusion is reached. In this way, within the dialogical relationship, all persons are equal, with each one treating the other as a meaningful contributor. Similarly, in a democracy all are equal before the law, and, as Dewey emphasizes, it is the freedom to express one's unique voice and the discipline to listen to others that enables an inquiry to move forward.

The dialogical participants will naturally have different interests, dispositions, social statuses, classes, races, genders, sexual orientations, ethnicities, religions and other markers of cultural and personal identities. Therefore, it almost goes without saying that the participants will have ideas, beliefs, and opinions that differ from one another. It is not surprising then that many of the dialogues end inconclusively, such as in the Meno (Plato, ed. 1963, 100a-b), where the questions of what virtue is and whether it is knowable are left unsettled. In such instances, Socrates recommends that the discussion be continued, if for no other reason, he suggests, that doing so would promote civility (Plato, 100b; Herman, 2017). Interestingly, and related to the needs of a democratic society, the root of the word, "civility," comes from civis, the city. Comparably, the Greek root of the word "polite" is polis, which also means the city. Thus, as Davetian (2009, p. 9) explains, civility (and politeness too) refer to a way of living when citizens depend

\footnotetext{
${ }^{3}$ Anytus will be one of the chief prosecutors at the trial of Socrates.
} 
on each other in complex social networks, or, in other words, as in a democracy. For Dewey (see in particular, 1916, chapter 26) the generation of new thinking and learning in the classroom and constructive living in the world are, in his words, forms of "morality."

When a dialogue does move toward a conclusion, an encounter with another person whose beliefs are different from or contrary to one's own encourages the original participants through the rules of dialogue to consider the possibility that the other's ideas might have something to contribute to one's own well-being. The dialogue requires that both participants take time to acknowledge more than one view of what each considers to be true and to open their minds to new perspectives. Thus, a dialogical society is a democratic society that calls its inhabitants, in recognizing their own ignorance, to know themselves. But why would a society that did not foster that virtue be unlivable? Simply put, a life unexamined would be driven entirely by desire and power where, as Shakespeare's Lear observed, "man's life would be cheap as beasts" (King Lear, 2005, Iliv423); and society would be, as Hobbes describes in Leviathan (1957, p. 190), a "war of every man against every man." A putatively democratic society significantly populated by such persons would be violent, chaotic and, as Plato astutely diagnosed, a society primed for tyranny (ed. 1963, Republic, 563d-569c).

Thus, we come around to the Jeffersonian claim that to avoid tyranny, a democratic polity requires an educated citizenry. For him, history was a key component of education to help citizens avoid the errors of the past. However, today, many stress the importance of studying civics (see, e.g., Callan, 1997). But for Socrates and Dewey, it was the practice of civics that was important: Citizens needed to become accustomed to, and skilled at, collaborative dialogues and selfexamination. An active citizen in the early history of the United States, Benjamin Franklin, exhibits both those traits in a letter he wrote in 1787 in support of the original American Constitution:

"I do not entirely approve of the Constitution at present, but I am not sure I shall never approve it, for having lived so long, I have experienced many instances of being obliged by better information or fuller consideration to change my opinions, even on important subjects, which I once thought right but found to be otherwise" (Franklin, 1954, p. 456).

In much more recent times, we were fortunate enough to participate as teachers in a public college that allowed, even encouraged its students to take up Franklin's form of self-improvement. Indeed, the college's somewhat unique design was commensurate with the practices and philosophy of both Socrates and Dewey.

\section{Empire State College}

In 1971, the State University of New York (SUNY) added a new college to its already large network of more than 60 community and four-year colleges and universities. Called "Empire State College" (ESC), the new institution attracted 
primarily working adults, although anyone who found traditional colleges inaccessible for whatever reason was also welcome to apply. The College was not explicitly founded on the ideas of John Dewey or the paradigm of Socratic dialogue. Rather, borrowing somewhat from Goddard College in Vermont and the Open University (OU) in Great Britain, faculty and students sought to create practical ways of offering a college-level education where students could learn what was valuable to them and faculty could responsibly supervise, assist and evaluate their learning. Those activities and procedures they set in motion turned out to have much in common with the philosophical ideas (although certainly not all the practices) of Dewey and Socrates.

First of all, classrooms were abolished. The very practical reason was that older students with work and family responsibilities simply did not have the time or opportunity to fit into their lives the typical classroom schedules of traditional schools. Thus, it was understood from the start that students would have to do much of their learning in their own time and at a place of their choosing. To provide proper supervision and necessary assistance, each student was assigned a faculty mentor who kept in touch by meeting his or her student periodically in a mutually convenient location - much as was done with tutorials at the OU (as shown in the film, Educating Rita directed by Gilbert, 1983). To make such meetings viable, faculty offices were made available in more than 50 different locations throughout the State of New York so that students did not have very long distances to travel. Where personal circums-tances or physical location made even that travel impossible, a special division of "distance education" was soon established where students met and stayed in touch with their mentors or adjunct instructors (referred to as tutors) solely by phone, mail, and eventually email.

From the absence of classes, all else followed. It was now possible for each student to select their own course of studies - and each course could be, and often was, highly individualized. Even if the subject matter was not unique, the books and assignments could be decided upon together by the student and the mentor to follow a student's specific intellectual interest as well as to address his or her academic needs. Because so many of these early students were adults already successful in their careers, the College also set up a process by which academic credit could be awarded for knowledge they had already acquired on their own. Degrees could not be awarded unless the learners completed a coherent and academically defensible plan of study. This plan consisted of a list of courses already completed elsewhere plus those they intended to take at the College. They had to defend this program in a written essay by showing how it provided them with appropriate breadth overall, and significant depth in single subject area of their choice. If they chose a traditional subject, such as in psychology, business, design, literature, or mathematics, they had to explain how their plan included all courses normally expected in that area.

The absence of classes also made it possible for the College to allow considerable flexibility in the completion of whatever course of study a student might have chosen. While a 16-week term still remained, the College created ways 
of giving the student either more or less time as was needed. ${ }^{4}$ Courses could be disciplinary, interdisciplinary or composed from topics of particular interest to the individual student. Resources could come from work and community activities, interviews with experts in the field, workshops, multi-media, articles and monographs. Textbooks were not needed to determine the structure and the content of the course; indeed, they were often used simply as back-up references. In the end, all that mattered was that college-level learning be accomplished, demonstrated, and carefully assessed.

Like the OU and other such institutions, ESC was intended from the outset to be non-elitist, especially evident in the custom of accepting every applicant who seemed capable of doing college-level learning. For the most part, the College gave applicants the benefit of the doubt when determining their readiness for academic study. Rather than entrance exams or letters of recommen-dation, the mentor met prospective students and often began, even then, to encourage them to share their prior learning experiences and future goals. Once enrolled, students would then be ready to work with a mentor in converting their educational aims and interests into actual courses of study. Even here, the flexibility of the College was useful. If, for example, after the first assignment, it turned out that the student had difficulty writing, the course could be easily altered so as to include more focus upon composition. So too could texts or other resources be changed, and even to some extent the course content. As long as academic quality remained high and no administrative rules broken, the mentor (not unlike the professor in the traditional classroom) was relatively unconstrained in deciding what students could learn.

As a result, it was the mentors who became the actual face of the College. As James Hall, the College's first president, described it:

"These faculty mentors carry out a complex role more characteristic of the undergraduate teacher of 40 years ago before education became compartmenttalized into sub-disciplinary specialists, counseling specialists, placement specialists, and student activities specialists. In the mentor role, these functions are brought back together again ... [and] is highly facilitative" (Hall, 1976, p. 99).

Thus, the success of the College depended heavily upon the quality of the mentor/student relationship. The mentor had to attend carefully to student needs, both academic and non-academic. The list of responsibilities included helping students to correctly identify courses of study appropriate in content and skill level; to select and locate appropriate learning resources, including qualified tutors; to design and process their degree plans; and to navigate the bureaucracy of the College. In addition, mentors had to support students when they were confronted with the myriad non-academic challenges often facing adult students: children who become sick, work demands that become overwhelming, or personal and financial crises that bring their lives to a standstill - all this without sacrificing

\footnotetext{
${ }^{4}$ In essence, for any particular course, the student paid for a given number of credits and a certain amount of instructor attention per credit.
} 
academic integrity. As one colleague remarked, "A good mentor means listening to most anything while still setting firm boundaries about almost everything."

\section{Socrates and Dewey at ESC}

Clearly, the Socratic spirit can be found within or behind every conversation between mentor and student. Quite frequently, even before students enrolled, the first question they heard was "What do you want to learn?" And discussion of that question would naturally encompass questions of why and eventually questions about how. All answers were taken seriously. And inevitably counter-questions often required responses from the mentor in areas in which he or she was not expert. Thus, the mentor often had to acknowledge ignorance which, perhaps unintentionally, reflected the Socratic stance of "knowing that one does not know." In this case, both student and mentor engaged in a common inquiry to explicate the nature of the subject and to examine its suitability for the student's expressed needs and purposes. Such discussions always implied claims about fundamental values and purposes of living, which, with further inquiry, often became explicit. In other words, what began as a merely academically practical discussion about what is to be learned became a discussion of the relationship between learning and the purposes of one's life. ${ }^{5}$ Almost effortlessly, it seems, conversations in this rather odd relationship exemplified in themselves how an examined life really does make life worth living.

The equality among participants so consonant with the Athenian democracy of Socrates' time was also very real in the mentor/student relationship in $20^{\text {th }}$ century New York. We too, of course, live in a society in which equality is a predominant aspiration, but it acquired special meaning (and perhaps a fuller realization) at the College. First, many faculty mentors at ESC, having been teachers at other colleges, may have never before actually spent time listening to their students. Almost without exception, mentors were impressed by what their students had to say. As adults, many of the students had accomplishments in fields totally unfamiliar to the mentor - steel manufacturing, brewery operations, adoption services, sports coaching, to name a few. Secondly, the process of uncovering the student's needs and interests was almost by definition a fully collaborative endeavor. Both students and mentors became active learners engaged in dialogue with each other. That this equality was truly achieved was documented year after year at graduation ceremonies, where one or another faculty member called upon to congratulate the students repeatedly said - "while we are pleased at how much you were able to learn at this college, we want to take this opportunity to thank you for how much we were able to learn from you."

Dewey's goals were also easily embedded in the mentor/student relationship that not only promoted democratic equality but the space and freedom students needed to take charge of their own learning, or, as Dewey would put it, to be their own agents. Moreover, to the extent that the mentor/student dialogue took the

\footnotetext{
${ }^{5}$ For other examples, see Daloz, 1999; Herman \& Mandell, 2004; Mandell \& Coulter, 2016.
} 
inquiry model seriously - that is, it began with, included, and ended with questions of some sort - the student was forced to do much more than simply listen and agree. As Finkel (2015) notes, learning requires the students to doubt, deny, question, speculate, imagine - all this and more was able to take place during meetings with their mentors. Instead of ingesting and regurgitating information isolated from their own experiences, students gained academic knowledge that actually made a difference in their lives. For them, knowing was not simply a matter of answering test questions correctly, but it involved investigating multiple perspectives, accepting doubt, and drawing tentative conclusions. Thus, students not only took ownership of their own learning, but they recognized that learning was never fully complete, that it was a life-long endeavor. Moreover, their thinking processes were expanded to accept provisionality and complexity - both critically important for living in a modern democratic society.

Another key Deweyan aim was to encourage diversity. To some extent this goal was realized in the mentoring sessions when, as was frequently the case, students brought up for discussion almost any new issue that concerned them at work, in the community, or even at home. In many instances, students would bring back the new ideas that emerged in discussion with their mentors to colleagues or family members. In other cases, behaviors or opinions expressed by others often provoked not only discussion between student and mentor, but they became the basis for subsequent courses. In the final analysis, however, the kind of "grownup" disposition espoused by Biesta (2017) - the ability to adjust one's ideas in the presence of many other ideas - was explicitly realized only in those instances when students interacted with others as part of their coursework. Yet, from a larger perspective, diversity was magnificently achieved at the College in that students were able to follow their own individual interests, ask their own questions, take seriously their own ideas, and strengthen their own sense of themselves as learners. As a result, as ESC graduates engaged with the world around them, they represented through their individualized learning experiences the very diversity Dewey argued that a democratic society needed. Thus, collectively they fulfilled Dewey's ideal of a democratic society of people who can share and examine each other's different ideas as they try to solve contemporary problems in productive and peaceful ways.

\section{The Demise of the Empire State College Mission}

Although the College still exists today, it has morphed into a large academic institution that provides mostly ready- made and limited standardized curricula through online courses. The progressive, flexible, highly individualized courses of study - those centered on the dialogical relationship between student and mentor prevailed more or less successfully only through the first 25 years of the college's nearly $50-$ year history. A number of factors seem to have been responsible for inducing the College to revert to more academically traditional policies and practices. Although certainly there were strong outside pressures, many of the immediate factors also had to do with the human constituents and the ways in 
which both individualized and dialogical education challenged students, faculty, and administrators.

\section{Students}

The student body at Empire State College consisted mainly of adults (on average around 38 years of age) who were understandably attracted to a college that did not have a campus or regularly scheduled week-day classes. As adults, however, the majority were already pre-occupied with other important and timeconsuming commitments, such as fulfilling family, work, and community responsibilities. Many also entered college expecting to be told what to do and to follow directions as expeditiously as possible. The reasons they sought a college degree varied considerably, but the vast majority shared the same desire to finish their education as quickly as possible. Thus, being invited into an intensely collaborative educational relationship with faculty, one where they were asked to participate in deeply examining their goals, designing their own curricula, and choosing appropriate learning activities, while also being expected to diligently examine and reflect upon each course of study - all this, though exhilarating, was often overwhelming. Good mentors were able to excite and engage students in their studies, but in the long run, for busy adults, such an education seemed to require much more time and effort than simply being told up front what was required. As online educational technology became increasingly available, students were attracted by a much simpler enterprise - working with any available computer at any time and any place on standardized courses in the virtual company of other students. Moreover, in that setting they could easily figure out on their own the least amount of work they had to do to pass a given course without engaging the subject as deeply as their mentors might have hoped. And, if students wanted to transfer to another college or go on to graduate school, they no longer had the burden of trying to explain an unusual and nontraditional learning experience to people accustomed to a very different form of education.

\section{Faculty}

From the beginning, there were always a significant number of faculty members who were unsympathetic to the College's original view of education. Some strongly objected in principle to the idea of individualized courses. Others believed that in giving weight to student interests and goals, their studies would lead to weak and sloppy academic outcomes. Even more worrisome, if the students had not completed a standardized curriculum, they might be unprepared to meet the standards of graduate school or advanced professional study. This led a number of faculty to be concerned about the College's reputation, particularly when students were able to receive college credit for work done entirely outside the academy. In terms of their lives as teachers, faculty also began to object to the workload. Just as at other SUNY and reputable private colleges, ESC faculty were expected, and in many instances deeply wanted, to engage in significant scholarship. Yet, mentoring and the continuous co-development of high-quality 
individualized studies also required considerable time and effort. Even faculty most devoted to the College's mission began to take shortcuts. For example, they started writing more highly prescriptive learning plans, which they frequently found reason to use more than once. And in meetings with students, the mentors found it easier to ask fewer questions and to deliver more of their own ideas in small-scale expositions. As time went on, individualized mentoring, faculty scholarship, and the considerable amount of institutional service the college demanded became unsustainable for many faculty. Monitoring large numbers of students, each learning in their own ways and for their own reasons, began to be seen as uselessly inefficient. As one colleague put it, "Who has time for this? Why spend 15 minutes letting a student discover something we can tell her in 2 seconds?"

\section{Administration}

The people who managed the academic affairs of the College - departmental chairs, deans and assistant deans, vice-presidents, the provost and president became increasingly distant from and uninvolved in educational activities. They had budgets to meet and certain goals to achieve (e.g., recruitment and retention, productive graduation rates, alumni contacts, grants and donations) that funded the costs of operating the institution, paying its personnel, and sustaining and improving its infrastructure. Moreover, the administrators, who answered to and served at the pleasure of the State University's Chancellor, were expected to conform to policies common to the entire network of colleges in the state university system. As economic considerations subordinated other concerns, colleges and universities across the nation, including ESC, increasingly bought into the business metaphor for education. ${ }^{6}$ Students (sometimes now called "customers") paid for the opportunity to earn degrees if they produced the required, standardized, and measurable learning outcomes. Clearly, ESC's individualized approach was a significant outlier within that model; and its administrators became increasingly unable to explain or defend the school, much less find an easy way to make it fit within a view of education as a modern-day industry. Moreover, administrators at other institutions regarded the flexibilities ESC offered its students as academically suspect. And within ESC itself, administrators and their staff saw those flexibilities as unnecessarily inconvenient for record keeping and external reporting. In all, ESC administration, isolated in large part from the faculty and students, gradually saw less and less reason to defend the idiosyncratic features of ESC to the outside world. Therefore, inside the College, the administration created policies that made it harder and harder for faculty who still supported the original conception of the College to resist pressures to become more prescriptive and traditional.

${ }^{6}$ For a recent exposition of this change from 1975 to 2000, see Gumport, 2019. 


\section{The Fragility of Deweyan and Dialogical Education}

It is indeed dispiriting to acknowledge that our experience at Empire State College is not an isolated illustration of the inability of progressive schools and dialogical education to endure. The University of Chicago Laboratory School in its original format under Dewey's direction, had an even shorter life than did ESC. Although the school still exists today, it is no longer a Deweyan or dialogical experiment based on freedom and equality (Jackson, 1990). Also, we cannot forget that Socrates was put on trial, found guilty and put to death for his free and egalitarian manner of inquiry and for his refusal to give it up. ${ }^{7}$ Of course, while small progressive schools can still be found across the world (e.g., the Round Square Schools), what now dominates the field of education today is the autocratic model. As Biesta (2017) puts it, "those who have an interest in teaching are not really interested in the freedom of the student" (p. 97). Freedom is something students are supposed to experience and deal with outside the school walls.

Why is this the case? Why was Socrates so violently renounced? And, as Jackson (1990, p. x) asks, "Why hasn't Dewey's influence as an educator been as widespread and enduring as he and others had hoped it would be?" In particular, what were the human dispositions that stood in the way? We identify and will discuss three that seem especially cogent to us: the demand for efficiency; the difficulty of self-knowledge; and the lure of power.

\section{The Demand for Efficiency}

As noted in the ESC case study, universities and colleges today increasingly regard themselves as businesses so as to compete in a modern economy. Along with productivity, efficiency becomes a primary goal. To keep costs low and to save time, products and services must be standardized. With student graduates as products, differences in student ability, interests, and goals are seen as obstacles to be managed rather than qualities to be welcomed. Moreover, when the processes of developing, documenting, and assessing the learning from individual courses of study is seen as unacceptably inefficient, standardization of course content becomes an imperative. From a business point of view, standardization is especially attractive when, as is the case today, readily available pre-designed courses are globally accessible through online course management systems. Also, instead of allowing students to create their own areas of specialization, it is far easier for universities to offer a finite set of ready-made options selected in advance in response to market demand or to match faculty expertise.

In this environment, perhaps it is not surprising that faculty and students too are attracted to efficiency; in the United States, for example, "wasting time" is considered a violation of a productive and moral life. ${ }^{8}$ Yet speed is not an appropriate measure of learning that consists of discovering, comprehending, and

\footnotetext{
${ }^{7}$ How ironic that Athens punished him for practicing a form of education seemingly so in keeping with the city's democracy.

${ }^{8}$ The classic discussion of this idea is Weber's The Protestant Ethic and the Spirit of Capitalism, 1905/2002.
} 
advancing previously unknown information and ideas. Instead, what matters is the extent to which the learners' minds are opened or transformed. Moreover, while we might view learning as an individual act, in truth it is not. Humans are social animals. Our very existence - our physical survival- depends on others; and advances in knowledge depend upon building upon what others have learned and discovered. Because so many variables go into the make-up of an individual person, it makes practical sense that people be able to share and continually reconsider their different points of view in seeking solutions to problems and a better understanding of life. But "saving time" is irrelevant to the success of that process. If people are in a hurry and let saving time become the driving force in the learning situation, an education that depends upon collaboration, discussion, reflection, and thought will necessarily be degraded. A demand for efficiency reduces freedom of choice, diversity of outcome, the attractiveness of collaboration, and the quality of the very learning processes Deweyan, Socratic, and other forms of democratic education promote.

\section{The Difficulty of Self-knowledge}

Related to lack of efficiency, objections were often raised at ESC about the amount of intellectual effort that mentoring and individualization involved. Dewey's school too was seen to demand too much of the teachers (Schwab, 1978, as cited in Jackson, 1990, p. xi). ESC's students also seemed to feel that while personalized learning was engaging and worthwhile, an information delivery system was much easier to manage in terms of time and effort. Of course, for the older adult students at ESC, time was a precious commodity, unlike the case with younger students such as those at Dewey's school. But one still has to ask what exactly was requiring so much time and effort here? On the face of it, why would a school that requires one to own up to one's ignorance and engage in selfexamination be seen as asking too much of its students and teachers?

One answer is that humans are pre-disposed to draw conclusions as quickly as possible, usually without the assistance of conscious thought (see, e.g., Coulter, 2002). It is easy to see why this might be a biological necessity, but it is not helpful in facing situations that are highly complex, as in today's developed world (see, e.g., Kegan, 1994). Self-knowledge, logical thinking, the search for corroboration, all require one to stop - to disrupt the flow of the normal busy-ness of living - in order to entertain a "state of doubt" (Dewey, 1910, p. 13). As Dewey describes it, "Reflective thinking is always more or less troublesome because it involves...willingness to endure a condition of mental unrest and disturbance... [which] is likely to be somewhat painful" (p. 13). As long as life seems to be going smoothly, we have no motivation to reflect upon our existing state and consider new directions. To actually change direction requires discontent with one's current condition, unexpected turns of events, and/or unmet needs (see, e.g., Mezirow, 1978, and MacKeracher, 2012). Thus, responding to this, or any, unsettled state clearly requires additional time and effort. Even then, it is the rare individual willing to take the time to look inward for explanations and solutions, or to remember (from our high school years) that: 
"The fault, dear Brutus is not in our stars,

But in ourselves, that we are underlings."

(Shakespeare, 2005, Julius Caesar, Iii141-142)

And those individuals inclined to self-examination often feel so inadequate to the task that, if they can afford it, they seek help from therapists. As a result, for most of us, the easiest and most immediate reaction to life disruptions is to look elsewhere than in ourselves for causes and remedies and to accept the first explanation that comes to mind.

But what about the other condition Socrates emphasized - the importance of recognizing one's own ignorance? Ignore that, and one is acting as though one need not learn anything more at all - a supposition flawed with both hubris and absurdity. However, honest acknowledgement of ignorance cannot take place unless one is able to stop and hold those first thoughts in abeyance until they are further examined for hidden errors, assumptions and biases. As Dewey suggests (and see also again Kegan, 1994), the change in perspective this kind of reflection requires is intellectually hard work. The Socratic dialogues illustrate how, even as one contributes to the conversation, one still must intellectually and imaginatively remove oneself from the particular values of one's personal, familial, cultural, economic, and professional contexts - nearly all the qualities that define one's self in the world. Understandably, this surrender of self, even temporarily, is difficult to achieve and sustain, much less to appreciate.

\section{The Lure of Power}

That surrender of self is not just difficult, time-consuming work. It is also frightening, because one leaves oneself unguarded and open to attack. Adding to the biological imperatives that already render the conditions of education in freedom so fragile is the compelling need to be in control of one's circums-tances. But one's "circumstances" are endless and incessant so long as one is alive; thus, the effort to achieve control becomes boundless. It becomes the lure of power.

This lure is a persistent theme in the history of western civilization. It is so ubiquitous that some believe it to be an elementary human characteristic. Freud, for example, speculated that the desire for control is as basic an appetite as lust (1920/1953, p. 36). Relevant to education, this desire for power and control demands that we be fully informed. As we so often hear, knowledge is power. Witness Adam and Eve who eat the forbidden fruit of tree of knowledge. Thus, they learn of good and evil, knowledge so powerful it infuriates a jealous God (Genesis, 2019, chapter 3). Similarly, Goethe's Mephistopheles (1949) successfully tempts Faust with the promise of knowing all things and thus of having the power to control them. And in modern times, we find scientists promising to achieve a "theory of everything," whereby all the phenomena of the universe are explained (Hawking, 1988; see also Hawking \& Mlodinow, 2010). Such a theory, even if it were merely taken to be provisionally true, would almost certainly be intelligible only to a few people, leaving the vast majority of us subject to their expert pronouncements and potent inventions. 
Moreover, in the traditional academic world, potency is implied in some of the words used for teachers: We are "professors" (those who profess); we are "schoolmasters" (masters of both students and the places they learn); we are "educators" (those who "lead out" others from ignorance to knowledge). The status difference between teacher and student is sharply defined and defended. "Faculty" (the word itself, a synonym for "potency" and "capability") submit their writings for "peer review"; but student papers and tests are graded only by teachers or teaching assistants. Faculty engage in "scholarship"; students are assigned research topics. When the distinction between teacher and student is so strong, there is no question about where all the authority lies and about which position is the more desirable. No wonder teachers find the role of autocrat very easy to assume.

A seemingly paradoxical but necessary corollary to the desire for control is the desire to submit - a desire as dangerous as its opposite. Not only do masters need slaves, as Hegel demonstrates (1967, p. 234-243), but followers can experience deep satisfaction in submitting to the will of a charismatic or august leader. As Dostoevsky's Grand Inquisitor in The Brothers Karamazov explains, people crave not freedom, but "miracle, mystery and authority" (2002, p. 255). A good $20^{\text {th }}$ century American example is Robert Penn Warren's Pulitzer Prize novel, All the King's Men (1946). And we see real life-examples today of this inclination to obey in the popularity of the "strongman" style leader in the United States and other constitutionally democratic nations. This inclination seems to spring from a sense of identification with the ruler that followers experience as they submit (see Adorno et al., 1950). So too do students find it easy, even comforting, to do what they are told by educators whom they admire.

\section{What Is To Be Done?}

It may be, as Jefferson advocated, that an educated citizenry is necessary for democracy to thrive. But if educational institutions primarily value efficiency, avoid the hard work of critical self-examination, promote knowledge as power, and maintain the traditional academic hierarchy of authoritative professors and submissive students, how can education offered by such colleges and universities preserve democracy? If, as we have argued, a truly democratic society must find a way to offer an education that allows students to learn in freedom, then obviously our highly autocratic forms of education must change. Given the various human dispositions that seem to undercut more democratic forms of education, is there any way that we, as individual scholars and teachers, can find ways of resisting the call for efficiency, restraining our attraction to power and control, and admitting to the limits of our intelligence? It may be beyond our collective abilities to substantially affect the external forces that are promoting autocracy and changing our universities into social industries rather than democratic greenhouses for individuals. But we believe that as educators, we do have the ability to change our own beliefs and behaviors and, in our individual classrooms, the freedom to implement new, democratic, and growth-inducing ways of teaching. 
In terms of personal development, we teachers must be willing to engage in serious self-examination. Often we hold conscious beliefs that contradict those created from prior experience, unexamined societal expectations, and tradition. Observation and research have shown that these tacit beliefs can sway, modify, and undermine what we may rationally determine to be true (see, e.g., Argyris, 1980; 1991). Until we uncover and acknowledge this conflict, our unconscious habits of thought get the better of our good intensions. Only when tacit beliefs are uncovered in a Socratic fashion can they be further examined and rendered open to change. It is this process, so similar to that of psychoanalytic therapy, that will allow the teacher to take up new approaches in the classroom that won't be undermined by unrecognized contrary beliefs.

Consonant with the freedom we advocate for students, teachers too, once they decide to change, should be free to explore and develop their own individualized ways of helping students learn. Although we have presented two coherent education models from ancient and modern history, many other scholars also advocate for more student freedom in formal education (see e.g., Langer, 1993; Mezirow, 2003; Paley, 1992; and Rogers, 1969; 1983). For a more recent example, a new teaching innovation is the "flipped classroom" (Reidsema, Kavanagh, Hadgraft, \& Smith, 2017) where students are expected to study texts and videos on their own and then spend class time solely on examining and discussing what they have learned. Collins \& Halverson (2018) offer numerous suggestions for using digital technology, not to standardize courses, but to make it easier for students to work collaboratively with others and to think for themselves. These sources, plus the philosophical underpinnings provided by Dewey and Socrates, may inspire teachers to reconsider the impact of lectures, standardized tests, and memorization on students who live in democratic societies. If so, is it too much to hope that we may then learn how to give our students more space to explore new ideas in their own ways, to accept doubt, uncertainty, and provisional solutions, to listen to and work productively with their colleagues? If we teachers can show ourselves to our students as uncertain, as able to relinquish control, as willing to forego efficiency for open-ended inquiry, will it be enough to help our students discover the freedom they experience to be worth the time and effort it demands - and worth more than the simple answers autocracy promises?

Even in the absence of ready answers to these questions, we do believe that change is possible. Consider, for example, Benjamin Franklin's life-long efforts at self-development, and that Dewey's Lab School and Empire State College were invented in the first place and did operate successfully for a period of time If we ourselves become the kind of learners and innovators in our classrooms that we hope our students will be, it is reasonable to hope that these students will carry on as citizens: alert, able, and willing to keep our democracies alive and vibrant. After all, regardless of their destructive dispositions, humans flourish when they are free to be curious and inventive (see Phelps, 2013). Thus, no matter that we cannot be sure of the outcome, our educational practices should nonetheless reflect this freedom, thoroughly and always. 


\section{References}

Adorno, T. W., Frenkel-Brunswik, E., Levinson, D., \& Sanford, N. (1950). The authoritarian personality. New York, NY: Harper Brothers.

Argyris, C. (1980). Some limitations of the case method: Experiences in a management development program. Academy of Management Review, 5(2), 291-298.

Argyris, C. (1991). Teaching smart people how to learn. Harvard Business Review, 69(3), 99-109.

Biesta, G. (2017). The rediscovery of teaching. New York: Routledge.

Callan, E. (1997). Creating citizens: Political education and liberal democracy. Oxford, UK: Oxford University Press.

Collins, A., \& Halverson, R. (2018). Rethinking education in the age of technology: The digital revolution and schooling in America ( $2^{\text {nd }}$ ed.). New York: Teacher's College Press.

Coulter, X. (2002). The role of conscious reflection in experiential learning. All About Mentoring, 24, 13-22.

Davetian, B. (2009). Civility: A cultural history. Toronto, CA: University of Toronto.

Daloz, L. A. (1999). Mentor: Guiding the journey of adult learners. San Francisco, CA: Jossey-Bass.

Dewey, J. (1910). How we think. Boston, MA: D.C. Heath.

Dewey, J. (1916). Democracy and education. New York, NY: Free Press.

Dewey, J. (1938). Experience and education. New York, NY: Collier.

Dostoevsky, D. (2002). The Brothers Karamazov. Translated by R. Pevear \& L. Volokhonsky. New York, NY: Vintage Books. [Original work published 1880].

Finkel, D. (2015). 5 ways to share math with kids. Retrieved from https://bit.ly/32m BH4b.

Foucault, M. (2010). The government of self and others: Lectures at the College de France, 1982-1983. Translated by G. Burchell. New York: NY: Picador.

Franklin, B. (1954). Speech in the convention: At the conclusion of its deliberations. In R. Ulrich (Ed.), Three thousand years of educational wisdom: Selections from great documents ( ${ }^{\text {nd }}$ ed.) (pp. 459-461). Cambridge, MA: Harvard University Press. [Original work published ca. 1787].

Freud, S. (1920/1953). Beyond the pleasure principle. In J. Strachey (Ed. \& Trans.), The standard edition of the complete psychological works of Sigmund Freud (Vol. XVIII, pp. 8-51). Retrieved from https://bit.ly/2Bj7E1B. [Original work published 1920].

Genesis (2019). In R. Alter (Ed. \& Trans.), The Hebrew Bible, Vol. 1: The five books of Moses, 3. New York: NY: Norton.

Gilbert, L. (Producer \& Director). (1983). Educating Rita [Motion Picture]. United Kingdom: Acorn Pictures.

Goethe, J. W. (1949). Faust: Part one (P. Wayne, Trans.) Baltimore, MD: Penguin Classics. [Original work published 1808].

Gumport, P. J. (2019). Academic fault lines: The rise of industry logic in public higher education. Baltimore, MD: John Hopkins University Press.

Habermas, J. (1990). Moral consciousness and communicative action. C. Lehnardt \& S. W. Nicholson (Trans). Cambridge, MA: MIT Press.

Hall, J. W. (1976). The faculty and the future. Alternative Higher Education, 1(2), 99110.

Hawking, S. (1988). A brief history of time. New York, NY: Bantam Books.

Hawking, S., \& Mlodinow, L. (2010). The grand design. New York, NY: Bantam Books.

Hegel, G. W. F. (1967). Phenomenology of mind (J.B. Baille, Trans). Evanston, IL: Harper $\&$ Row. (Original work published 1807). 
Herman, L. (2017). Is the authority in the dialogue? A memorandum. In K. Jelly \& A. Mandell (Eds.), Principles, practices, and creative tensions in progressive higher education: One institution's struggle to sustain a vision (pp. 93-109). Rotterdam, The Netherlands: Sense.

Herman, L. \& Mandell, A. (2004). From teaching to mentoring: Principle and practice, dialogue and life in adult education. New York, NY: RoutledgeFalmer.

Hobbes, T. (1957). Leviathan. In T. V. Smith \& M. Grene (Eds.), From Descartes to Locke (chapter 13). Chicago: IL: University of Chicago Press. [Original work published 1671].

Jackson, P. W. (1990). Introduction. In J. Dewey, The school and society/The child and the curriculum (pp. ix-xxxvii). Chicago: University of Chicago Press.

Jefferson, T. (2011). Notes on the State of Virginia: Query XIV. In M.D. Peterson (Ed.), Thomas Jefferson writings (pp. 256-275). New York, NY: Library of America. [Original work published ca. 1781].

Kegan, R. (1994). In over our heads: The mental demands of modern life. Cambridge, MA: Harvard University Press.

Langer, E. J. (1993). A mindful education. Educational Psychology, 28(1), 43-50.

Levitsky, S., \& Zeblatt, D. (2018). How democracies die. New York: Broadway Books.

Lindeman, E. (1927). The meaning of adult education. New York: New Republic.

MacKeracher, D., (2012). The role of experience in transformative learning. In E. W. Taylor \& P. Cranton (Eds.), The Handbook of Transformative Learning: Theory, Research and Practice (pp. 342-354). San Francisco, CA: Jossey-Bass.

Mandell, A., \& Coulter, X. (2016). Academic mentoring as precarious practice. In K. Peno, E.M. S. Mangiante, \& R. A. Kenahan (Eds.), Mentoring in formal and informal contexts (pp. 23-42). Charlotte, NC: Information Age Publishing.

Mayhew, K. D., \& Edwards, A. C. (1936/1965). The Dewey school: The laboratory school of the University of Chicago 1896-1903. New Brunswick, NJ: Aldine Transaction.

Mezirow, J. (1978). Education for perspective transformation: Women's re-entry programs in community colleges. New York, NY: Teachers College.

Mezirow, J. (2003). Transformative learning and discourse. Journal of Transformative Education, 1(1), 58-63.

Murphy, J. (2011). Assertiveness. Seattle, WA: Amazon.

Paley, V.G. (1992). You can't say you can't play. Cambridge MA: Harvard University Press.

Phelps, E., (2013). Mass flourishing: How grassroots innovation created jobs, challenge, and change. Princeton, NJ: Princeton University Press.

Plato (1963). Apology (H. Tredennick, Trans.). In E. Hamilton \& H. Cairns (Ed.), The Collected Dialogues of Plato (pp. 3-26). Princeton, NJ: Princeton University Press.

Plato (1963). Meno (W. K. C. Guthrie. Trans.). In E. Hamilton \& H. Cairns (Ed.), The Collected Dialogues of Plato (pp. 353-384). Princeton, NJ: Princeton University Press.

Plato 1963). Phaedrus (R. Hackforth, Trans.). In E. Hamilton \& H. Cairns (Ed.), The Collected Dialogues of Plato (pp. 475-525). Princeton, NJ: Princeton University Press.

Plato (1963). Republic (P. Shorey, Trans.). In E. Hamilton \& H. Cairns (Ed.), The Collected Dialogues of Plato (pp. 575-844). Princeton, NJ: Princeton University Press.

Plato (1963). Symposium (M. Joyce, Trans.). In E. Hamilton \& H. Cairns (Ed.), The Collected Dialogues of Plato (pp. 526-574). Princeton, NJ: Princeton University Press. 
Pomeroy, S., Burstein, S. M., Donlan, W., \& Roberts, J. T. (1999). Ancient Greece: A political, social and, cultural history. New York, NY: Oxford University Press.

Reidsema, C., Kavanagh, L., Hadgraft, R., \& Smith, H. (Eds.) (2017). The flipped classroom: Practice and practices in higher education. Singapore: Springer.

Rogers, C. R. (1969). Freedom to learn. Columbus, OH: Charles Merrill.

Rogers, C. R. (1983). Freedom to learn for the 80's. New York, NY: Macmillan.

Shakespeare, W. (2005). Julius Caesar. In D. Jowett, W. Montgomery, G. Taylor, \& S. Wells (Eds.), The Oxford Shakespeare: The complete works, $2^{\text {nd }}$ edition. Oxford, UK: Oxford University Press. [Original work published 1599].

Shakespeare, W. (2005). King Lear [Quarto text]. In D. Jowett, W. Montgomery, G. Taylor, \& S. Wells (Eds.). The Oxford Shakespeare: The complete works, $2^{\text {nd }}$ edition. Oxford, UK: Oxford University Press. [Original work published ca.1605].

State University of New York (2014). Articles IX and X. In The State University of New York: The policies and procedures of the Board of Trustees (pp. 15-16). Albany, NY: SUNY.

Warren, R. P. (1946). All the king's men. New York, NY: Harcourt, Brace.

Weber, M. (1905/2002). The Protestant ethic and the spirit of capitalism: And other writings (P. Baehr \& G. C. Wells, Trans.). New York, NY: Penguin. 
